\title{
Prevalence and Associated Factors of TB Co-Morbidity Among HIV Sero-Positive Individuals in Shegaw Motta District Hospital, Ethiopia
}

This article was published in the following Dove Press journal: International Journal of General Medicine

\author{
Abebe Fenta' \\ Gebreselassie Demeke' \\ Abebaw Bitew' \\ Destaw Kebede ${ }^{2}$ \\ Tadesse Hailu ${ }^{3}$ \\ 'Health Science College, Debremarkos \\ University, Debre Markos, Ethiopia; \\ ${ }^{2}$ Shegaw Motta District Hospital, Motta, \\ Ethiopia; ${ }^{3}$ College of Medicine and Health \\ Sciences, Bahir Dar University, Bahir Dar, \\ Ethiopia
}

Background: Tuberculosis (TB) is a major public health problem among people living with Human Immunodeficiency Virus (HIV) in resource-limited countries like Ethiopia. Up-todate information regarding TB co-morbidity and determinant factors among HIV seropositive individuals is lacking in the study area.

Objective: This study aimed to determine the prevalence of TB co-morbidity and their determinants among HIV sero-positive individuals in Shegaw Motta district hospital.

Methods: A cross-sectional study was conducted among 326 people living with HIV from February to April 2019, in Shegaw Motta district hospital. The systematic random sampling technique was used to select the study participants. Data were entered into the EpiData version 3.1 and analysis was done using SPSS version 20.0.

Results: The prevalence of TB/HIV co-infection was $18.1 \%$. TB/HIV patients whose drunk alcohol $(\mathrm{AOR}=2.36,95 \% \mathrm{CI}=1.07-5.19), \mathrm{BMI}<16(\mathrm{AOR}=19.13,95 \% \mathrm{CI}=4.14-88.36)$, and BMI ranges between 16 and $18.5(\mathrm{AOR}=9.78,95 \% \mathrm{CI}=3.07-31.19)$, World Health Organization (WHO) clinical stage IV $(\mathrm{AOR}=23.02,95 \% \mathrm{CI}=3.76-140.97)$, WHO clinical stage III $(\mathrm{AOR}=14.36,95 \% \mathrm{CI}=3.50-58.92)$, and WHO clinical stage II (AOR=4.17, 95\% $\mathrm{CI}=1.34-13.01)$, bedridden $(\mathrm{AOR}=13.79,95 \% \mathrm{CI}=5.44-34.95)$ and ambulatory functional status $(\mathrm{AOR}=5.30,95 \% \mathrm{CI}=1.87-15.05)$ were significant predictors for $\mathrm{TB} / \mathrm{HIV}$ coinfection.

Conclusion: The prevalence of TB among HIV sero-positive individuals is high. Determinant factors, including drinking alcohol, BMI, WHO clinical stage and functional status, were significant predictors for TB/HIV co-infections. Therefore, diagnosis of TB among sero-positive individuals should be strengthened in health institutions.

Keywords: prevalence, tuberculosis; TB, HIV, Ethiopia
Correspondence: Abebe Fenta Email abebefenta16@gmail.com

\section{Introduction}

Tuberculosis (TB) is among the major causes of death for people living with Human Immunodeficiency Virus (HIV) which accounts about $25 \%$ of all causes of the deaths. ${ }^{1}$ There is a moderately high prevalence of TB co-morbidity among HIV sero-positive individuals, since HIV promotes the progression of latent or recent infections of mycobacterium TB to active disease and HIV also increases the rate of occurrence of TB. On the other hand, HIV infected clients are more susceptible to TB infection. ${ }^{2,3}$

HIV infection contributes to the incidence of TB in the world, by decreasing in cell-mediated immunity of the people. It also alters the pathogenesis of TB, greatly 
promoting the risk of developing disease and leads to the occurrence of extra pulmonary TB. Though, TB/HIV coinfection is both treatable and preventable, the prevalence rates continue to increase in developing countries where TB/HIV co-infection are endemic., ${ }^{4,5}$

Globally, there were an estimated 9 million TB incidence cases in 2013 with 13\% TB/HIV co-infection. Likewise, 1.5 million TB infected clients and 0.4 million TB/HIV co-infected individuals were died in the world. ${ }^{6}$ The World Health Organization (WHO) recorded that, Ethiopia ranks 7 th among the 22 high burden countries with TB/HIV co-infection in the world. ${ }^{7}$

TB is still a major challenge in Ethiopia and driven by the HIV epidemic. It has become a formidable threat, calling for concerted efforts by concerned bodies. ${ }^{8}$ Coinfections of TB/HIV has a negative impact especially in developing countries like Ethiopia. ${ }^{9}$ Previous studies showed that being HIV infected is not the only predictor for being infected with TB, and there are other determinant predictors that contribute to the occurrence of TB among HIV sero-positive individuals. ${ }^{10-12}$ Understanding the predictors of TB among HIV sero- positive individuals is crucial for Ethiopia to improve TB/HIV co-infected patients' management. Routine hospital reports in the study area indicated that, the numbers of HIV sero-positive clients are increasing; however, detection of TB among HIV sero-positive clients are hardly practiced. In addition, determinant factors associated with TB co-morbidity were poorly addressed. Hence, the present study was conducted to assess the prevalence and determinant factors associated with TB co-morbidity among HIV seropositive individuals in Shegaw Motta district hospital, Northwest Ethiopia.

\section{Methods}

\section{Study Design, Period and Area}

Institution-based cross-sectional study was conducted among HIV sero-positive patients from February to April, 2019 at Shegaw Motta district hospital AntiRetroviral therapy clinic, East Gojjam, Amhara region. Motta is placed $365 \mathrm{~km}$ from Addis Ababa (capital city of the Ethiopia), $120 \mathrm{~km}$ far from Bahir Dar (capital city of the Amhara region) and $196 \mathrm{~km}$ away from DebreMarkos (capital city of East Gojjam zone). The total population in the town was 44,914 (19,972 males and 24,942 females). ${ }^{13}$ In the town, there is 1 government health center, 1 specialized higher clinic and 3 medium clinics which are currently providing TB diagnostic services. Shegaw Motta district hospital is the main health services lender institution in the area. ${ }^{13}$

\section{Study Population and Sample Size Determination}

All HIV sero-positive clients whose age $>18$, visitShegaw Motta district hospital antiretroviral therapy (ART) clinic and volunteer to participate during the study period were included in the study. A total of 326 participants were included using systematic random sampling technique. The sample size for this study was computed by a single population proportion formula by using $7.5 \%$ prevalence from a previous study, ${ }^{14} 3 \%$ margin of error and $95 \%$ CI. The sample size was determined as follows:

$$
N=\frac{(Z a / 2)^{2} p . q}{d^{2}} n=\frac{(1.96)^{2} 0.075 *(1-0.075)}{(0.03)^{2}}=296
$$

By including $10 \%$ non-response rate, the final sample size was $296+30=326$.

\section{Data Collection, Sampling Procedure and Sample Processing}

Two nurses who were working in the ART clinic were selected for data collection and training was given on how to collect the data. Both primary and secondary data were collected through interviewing people living with HIV and reviewing their cards in ART clinic.

The sputum samples were collected three times (spot-morning-spot) by using sterile leakproof plastic containers from each study participant. These samples were decontaminated with sodium hypochlorite and concentrated by centrifugation subsequently freeing the bacteria ready for staining. Smears were prepared, dried with air, fixed and stained with Ziehl-Neelsen staining technique. The stained slides were then carefully examined using a microscope to confirm the presence of acid-fast bacilli. The final result was defined as positive when two or more smears positive for acidfast staining. ${ }^{15}$

\section{Data Quality Control}

A structured questionnaires were prepared in English and translated into the Amharic language and then back-translated into English to check for any inconsistencies or distortions in the meaning of words. Pretest 
was done among $49(15 \%)$ randomly selected people living with HIV before the actual date of the study period at Debre Mariam health center. Besides, the principal investigator was supervising the data collectors to keep the validity of the data during the data collection period.

\section{Data Analysis}

Data were entered in EpiData version 3.1 and analyzed using SPSS version 20 statistical software. The prevalence of TB/HIV co-infection was determined using descriptive statistics. Chi square test and independent $t$-test were used to test the relationship between each variable and TB/HIV co-infection status. Multivariate logistic regression was done by entering all variables with $\mathrm{P}$ value less than 0.25 in the Univariate analysis. Finally, logistic regression with a forward likelihood selection method with $P$-value $<0.05$ was used to identify the factors associated with TB/HIV co-infection. Variables with $P$-value $<0.05$ was considered as statistically significant.

\section{Operational Definition Working}

Able to perform usual work in or out of the house.

\section{Ambulatory}

Able to perform activities of daily living.

\section{Bedridden}

Not able to perform activities of daily living.

\section{Poor Adherence}

If the percentage of missed dose is between $<85 \%$ ( $>6$ doses of 30 doses or $>9$ dose of 60 doses) as documented by ART physician.

\section{Alcohol Use}

Study participants who answered "yes" in this study were defined as ever or current drinking and those who answered "no" were defined as non-drinking.

\section{Smoking Status}

Study participants who answered "yes" in this study were defined as ever or current smoking and those who answered "no" were defined as non-smoking.

Table I Socio-Demographic Characteristics of HIV Sero-Positive Clients at Shegaw Motta District Hospital from February to April, 2019

\begin{tabular}{|c|c|c|}
\hline Variables & Category & Frequency (\%) \\
\hline Age & $\begin{array}{l}\leq 24 \\
25-44 \\
45-64 \\
\geq 65\end{array}$ & $\begin{array}{l}72(22.1) \\
156(47.9) \\
81(24.8) \\
17(5.2)\end{array}$ \\
\hline Sex & $\begin{array}{l}\text { Male } \\
\text { Female }\end{array}$ & $\begin{array}{l}137(42.0) \\
189(58.0)\end{array}$ \\
\hline Religion & $\begin{array}{l}\text { Orthodox } \\
\text { Muslim } \\
\text { Protestant }\end{array}$ & $\begin{array}{l}232(7 \mid .2) \\
83(25.5) \\
I I(3.4)\end{array}$ \\
\hline Residence & $\begin{array}{l}\text { Urban } \\
\text { Rural }\end{array}$ & $\begin{array}{l}\text { I } 82(55.8) \\
\text { | } 44(44.2)\end{array}$ \\
\hline Marital status & $\begin{array}{l}\text { Single } \\
\text { Married } \\
\text { Divorced } \\
\text { Widowed }\end{array}$ & $\begin{array}{l}\text { II } 3(34.7) \\
142(43.6) \\
41(12.6) \\
30(9.2)\end{array}$ \\
\hline Educational Status & $\begin{array}{l}\text { No education } \\
\text { Primary school } \\
\text { Secondary school } \\
\text { Certificate and above }\end{array}$ & $\begin{array}{l}75(23.0) \\
136(41.7) \\
64(19.6) \\
51(15.6)\end{array}$ \\
\hline Occupation & $\begin{array}{l}\text { Employed } \\
\text { Unemployed }\end{array}$ & $\begin{array}{l}133(40.8) \\
193(59.2)\end{array}$ \\
\hline
\end{tabular}




\section{Results}

\section{Socio-Demographic Characteristics of Study Participants}

A total of 326 respondents participated in the present study with a $100 \%$ response rate. One hundred fifty-six $(47.8 \%)$ respondents' were between 25 and 44 years of age. The mean age of the respondents was 36.11 years with a standard deviation of 13.96 years. The majority of respondents accounted (189; 58.0\%) females (232; $71.2 \%$ ) orthodox religion followers $(182 ; 55.8)$ urban dwellers $(142 ; 43.6 \%)$ married $(136 ; 41.7 \%)$, completed primary education and unemployed (193; 59.2\%) (Table 1).

\section{Prevalence of TB Co-Morbidity Among HIV Sero-Positive Individuals}

The prevalence rate of TB/HIV co-infection was 59 (18.1\%). The majority of TB/HIV-co infection respondents $(24 ; 40.7 \%)$ ranged in age between 25 and 44 years, followed by $20(33.9 \%)$ between 45 and 64 years. The high prevalence rate of TB/HIV co-infection was obtained among females (32; 54.2\%), Orthodox religion followers $(44 ; 74.6 \%)$, urban dwellers (31; $52.5 \%)$, unmarried $(29 ; 49.2 \%)$, non-educated (22; $37.3 \%)$, and unemployed (37; 62.7\%) HIV sero-positive individuals (Table 2). As indicated in the Chi-square test, the TB/HIV co-infection was significantly associated with marital status and educational status $(P$ value $<0.05$ ) (Table 2)

Among TB/HIV co-infected patients, the majority were non-smokers $(38 ; 64.4 \%)$, alcohol drinkers $(31 ; 52.5 \%)$, WHO clinical stage of III $(28 ; 47.5 \%)$, and had $\leq 200$ baseline CD4 count (45; 76.3\%) (Table 3).

The Chi-square test showed that the TB/HIV co infection was significantly associated with smoking status, alcohol intake, BMI, baseline CD4 count, baseline WHO clinical stage, baseline functional status, missed taking HIV medication and ART status $(P$-value $<0.05)$ (Table 3).

Table 2 The Prevalence of TB Co-Morbidity Among HIV Sero-Positive Clients Based on Socio-Demographic Characteristics at Shegaw Motta District Hospital from February to April, 2019

\begin{tabular}{|c|c|c|c|c|}
\hline \multirow[t]{2}{*}{ Variables } & \multirow[t]{2}{*}{ Category } & \multicolumn{3}{|c|}{ TB Infection } \\
\hline & & Yes $[n(\%)]$ & No $[n(\%)]$ & $\chi^{2}$ (p-value) \\
\hline Age & $\begin{array}{l}\leq 24 \\
25-44 \\
45-64 \\
\geq 65\end{array}$ & $\begin{array}{l}12(20.3) \\
24(40.7) \\
20(33.9) \\
3(5.1)\end{array}$ & $\begin{array}{l}60(22.5) \\
132(49.4) \\
61(22.8) \\
14(5.2)\end{array}$ & 0.354 \\
\hline Sex & $\begin{array}{l}\text { Male } \\
\text { Female }\end{array}$ & $\begin{array}{l}27(45.8) \\
32(54.2)\end{array}$ & $\begin{array}{l}110(41.2) \\
153(58.8)\end{array}$ & 0.561 \\
\hline Religion & $\begin{array}{l}\text { Orthodox } \\
\text { Muslim } \\
\text { Protestant }\end{array}$ & $\begin{array}{l}44(74.6) \\
12(20.3) \\
3(5.1)\end{array}$ & $\begin{array}{l}188(70.4) \\
71(26.6) \\
8(3.0)\end{array}$ & 0.476 \\
\hline Residence & $\begin{array}{l}\text { Urban } \\
\text { Rural }\end{array}$ & $\begin{array}{l}3 I(52.5) \\
28(47.5)\end{array}$ & $\begin{array}{l}|5|(56.6) \\
\mid I 6(43.3)\end{array}$ & 0.664 \\
\hline Marital status & $\begin{array}{l}\text { Single } \\
\text { Married } \\
\text { Divorced } \\
\text { Widowed }\end{array}$ & $\begin{array}{l}29(49.2) \\
17(28.8) \\
8(13.6) \\
5(8.5)\end{array}$ & $\begin{array}{l}84(31.5) \\
125(46.8) \\
33(12.4) \\
25(9.4)\end{array}$ & $0.045^{*}$ \\
\hline Educational Status & $\begin{array}{l}\text { No education } \\
\text { Primary school } \\
\text { Secondary School } \\
\text { Certificate and above }\end{array}$ & $\begin{array}{l}22(37.3) \\
18(30.5) \\
12(20.3) \\
7(11.9)\end{array}$ & $\begin{array}{l}53(19.9) \\
118(44.2) \\
52(19.5) \\
44(16.5)\end{array}$ & $0.026 *$ \\
\hline Occupation & $\begin{array}{l}\text { Employed } \\
\text { Unemployed }\end{array}$ & $\begin{array}{l}22(37.3) \\
37(62.7)\end{array}$ & $\begin{array}{l}\text { III (4I.6) } \\
\text { I56(58.4) }\end{array}$ & 0.562 \\
\hline
\end{tabular}

Note: *The relationship is a significant at $\alpha=0.05$. 
Table 3 Risk Factors of TB/HIV Co-Infection Among HIV Sero-Positive Clients at Shegaw Motta District Hospital from February to April, 2019

\begin{tabular}{|c|c|c|c|c|}
\hline \multirow[t]{2}{*}{ Variables } & \multirow[t]{2}{*}{ Category } & \multicolumn{3}{|c|}{ TB/HIV Co Infection } \\
\hline & & Yes $[n(\%)]$ & No $[n(\%)]$ & $\chi^{2}$ (P-value) \\
\hline Family size & $\begin{array}{l}I-5 \\
>5\end{array}$ & $\begin{array}{l}40(67.8) \\
19(32.2)\end{array}$ & $\begin{array}{l}\text { I76(65.9) } \\
91(34.1)\end{array}$ & 0.879 \\
\hline Smoking status & $\begin{array}{l}\text { Yes } \\
\text { No }\end{array}$ & $\begin{array}{l}21(35.6) \\
38(64.6)\end{array}$ & $\begin{array}{l}57(21.3) \\
210(78.7)\end{array}$ & $0.028^{*}$ \\
\hline Alcohol intake & $\begin{array}{l}\text { Yes } \\
\text { No }\end{array}$ & $\begin{array}{l}31(52.5) \\
28(47.5)\end{array}$ & $\begin{array}{l}69(25.8) \\
198(74.2)\end{array}$ & $0.000 *$ \\
\hline BMI & $\begin{array}{l}<16 \\
16-18.5 \\
18.5-24.5 \\
>24.5\end{array}$ & $\begin{array}{l}17(28.8) \\
14(23.7) \\
22(37.3) \\
6(10.2)\end{array}$ & $\begin{array}{l}16(6.0) \\
58(21.7) \\
165(61.8) \\
28(10.5)\end{array}$ & $0.000 *$ \\
\hline Baseline CD4 count & $\begin{array}{l}\leq 200 \\
>200\end{array}$ & $\begin{array}{l}45(76.3) \\
14(23.7)\end{array}$ & $\begin{array}{l}163(61.0) \\
104(39.0)\end{array}$ & $0.035^{*}$ \\
\hline Baseline WHO clinical stage & $\begin{array}{l}\text { I } \\
\text { II } \\
\text { III } \\
\text { IV }\end{array}$ & $\begin{array}{l}3(5.1) \\
9(15.3) \\
28(47.5) \\
19(32.3)\end{array}$ & $\begin{array}{l}46(17.2) \\
96(36.0) \\
118(44.2) \\
7(2.6)\end{array}$ & $0.000 *$ \\
\hline Baseline functional status & $\begin{array}{l}\text { Working } \\
\text { Ambulatory } \\
\text { Bedridden }\end{array}$ & $\begin{array}{l}12(20.3) \\
11(18.6) \\
36(61.0)\end{array}$ & $\begin{array}{l}177(66.3) \\
63(23.6) \\
27(10.1)\end{array}$ & $0.000 *$ \\
\hline Missed taking HIV medication & $\begin{array}{l}\text { Yes } \\
\text { No }\end{array}$ & $\begin{array}{l}42(7 \mid .2) \\
17(28.8)\end{array}$ & $\begin{array}{l}21(7.9) \\
246(92.1)\end{array}$ & $0.000 *$ \\
\hline ART status & $\begin{array}{l}\text { Yes } \\
\text { No }\end{array}$ & $\begin{array}{l}50(84.7) \\
9(15.3)\end{array}$ & $\begin{array}{l}198(74.2) \\
69(25.8)\end{array}$ & $0.043^{*}$ \\
\hline
\end{tabular}

Note: $*$ The relationship is a significant at $\alpha=0.05$.

\section{Multivariate Analysis of Determinants of TB/HIV Co-Infection}

In the Univariate analysis, $p$-value $\leq 0.25$ was used for selection of variables in the multivariate analysis. Based on this alcohol intake, BMI, baseline WHO clinical stage and baseline functional status were selected by forward likelihood logistic regression method. After adjusting other determinant factors in the Univariate analysis, patients who drank alcohol were 2.36 times more likely to develop TB than those who did not drink $(\mathrm{AOR}=2.36,95 \% \mathrm{CI}=1.07-5.19)$. The present study stated that HIV cases whose BMI was less than 16 were 19.13 times more likely to develop TB compared to those with a BMI greater than $24.5(\mathrm{AOR}=19.13,95 \% \mathrm{CI}=4.14$ 88.36). This study discovered that respondents whose BMI ranges between 16 and 18.5 were ten times more likely to develop TB compared to those with a BMI greater than 24.5 respectively (AOR $=9.78,95 \% \mathrm{CI}=3.07-31.19)$ (Table 4).
In the multivariate analysis, patients with WHO clinical stage IV were 23.02 more likely to develop TB than that of the patients in WHO clinical stage I $(\mathrm{AOR}=23.02$, 95\% CI=3.76-140.97). Similarly, patients with WHO clinical stage III were about 14.36 more likely to develop TB than those patients in WHO clinical stage I $(\mathrm{AOR}=14.36$, 95\% CI $=3.50-58.92)$. Patients with bedridden baseline functional status $(\mathrm{AOR}=13.79,95 \% \mathrm{CI}=5.44-34.95)$ had an increased risk to develop TB than working baseline functional status. Furthermore, ambulatory patients were 5.30 times more likely to develop TB than those working patients (AOR=5.30, 95\% CI=1.87-15.05) (Table 4).

\section{Discussion}

Infection of HIV increases the individuals' susceptibility to TB by impairing the immune response to mycobacterium infection. ${ }^{3}$ The prevalence of TB co-morbidity in HIV 
Table 4 Multi-Covariate and Bivariate Analysis Result Between TB/HIV Co-Infection and Predictor Variables Among HIV SeroPositive Patients at Shegaw Motta District Hospital from February to April, 2019

\begin{tabular}{|c|c|c|c|c|c|}
\hline Variables & Category & COR(95\% Cl) & $P$-value & AOR(95\% CI) & $P$-value \\
\hline Alcohol intake & $\begin{array}{l}\text { Yes } \\
\text { No }\end{array}$ & $\begin{array}{l}3.177(1.78-5.67) \\
\text { I }\end{array}$ & $0.000 *$ & $\begin{array}{l}2.358(1.07-5.19) \\
1\end{array}$ & $0.033^{*}$ \\
\hline BMI & $\begin{array}{l}<16 \\
16-18.5 \\
18.5-24.5 \\
>24.5\end{array}$ & $\begin{array}{l}4.402(1.79-10.81) \\
7.969(3.53-18.00) \\
4.958(1.63-15.12) \\
1\end{array}$ & $\begin{array}{l}0.00 I^{*} \\
0.000^{*} \\
0.005^{*}\end{array}$ & $\begin{array}{l}19.125(4.14-88.36) \\
9.78 \mid(3.07-31.19) \\
3.172(0.87-11.54) \\
1\end{array}$ & $\begin{array}{l}0.000^{*} \\
0.000^{*} \\
0.080\end{array}$ \\
\hline WHO clinical stage & $\begin{array}{l}\text { I } \\
\text { II } \\
\text { III } \\
\text { IV }\end{array}$ & $\begin{array}{l}\text { I } \\
41.619(9.72-178.19) \\
28.952(9.60-87.29) \\
\text { II.439(4.38-29.86) }\end{array}$ & $\begin{array}{l}0.000^{*} \\
0.000^{*} \\
0.000 *\end{array}$ & $\begin{array}{l}\text { I } \\
4.17 \mid(|.34-| 3.01) \\
\mid 4.360(3.50-58.92) \\
23.016(3.76-\mid 40.97)\end{array}$ & $\begin{array}{l}0.014 * \\
0.000^{*} \\
0.001 *\end{array}$ \\
\hline Functional status & $\begin{array}{l}\text { Working } \\
\text { Ambulatory } \\
\text { Bedridden }\end{array}$ & $\begin{array}{l}\text { I } \\
7.636(3.39-17.19) \\
19.667(9.12-42.42)\end{array}$ & $\begin{array}{l}0.000 * \\
0.000 *\end{array}$ & $\begin{array}{l}\text { I } \\
5.304(|.87-| 5.05) \\
\text { |3.789(5.44-34.95) }\end{array}$ & $\begin{array}{l}0.002 * \\
0.000 *\end{array}$ \\
\hline
\end{tabular}

Notes: I= Reference Category, *Odds Ratio is a significant at $\alpha=0.05$.

Abbreviations: $\mathrm{COR}$, crude odds ratio; $\mathrm{AOR}$, adjusted odds ratio; $\mathrm{Cl}$, confidence interval.

infected adults in the present study was $18.1 \%$. This finding is in line with studies conducted in India and Brazil in which the prevalence is $18.9 \%$ and $19 \%$, respectively. ${ }^{16,17}$ But, it is lower than previously reported $34.4 \%$ in India, ${ }^{18}$ $32.8 \%$ in Nigeria ${ }^{19}$ and $33 \%$ in Ethiopia. ${ }^{20}$ Likewise, it is slightly lower than $25.5 \%$ pooled prevalence in the Meta analysis done in Ethiopia. ${ }^{21}$ However, the findings of this study are higher compared to studies conducted in Ethiopia $(7.5 \%),{ }^{14}$ Nigeria $(7.8 \%)^{2}$ and Tanzania $(8.5 \%){ }^{22}$ These variations might partly be accounted for by the following reasons: coverage level of highly active antiretroviral treatment (HAART), under-reporting, difference in TB diagnosis, epidemiology of TB in different countries and study methodology applied.

Alcohol consumption was the one predictor variable for TB/HIV co-infection in HIV positive individuals in the present study. A study conducted in West Africa recorded similar findings where alcohol consumption is the risk factor for the development of $\mathrm{TB}^{23}$ In contrast, a study from the Gambia reported that alcohol use is not associated with TB. ${ }^{24}$ The difference might be due to the variation in the amount of alcohol in taken and religion. In some religions, Islam for instance, drinking alcohol is not allowed.

The current study revealed that HIV clients whose BMI is less than 16 and where BMI ranges between 16 and 18.5 were at higher risk of developing TB $(\mathrm{P}<0.001)$. This is comparable with a study done in Uganda among patients with HIV/AIDS in the hospital where a BMI less than 20 was a significant predictor of co-infection of $\mathrm{TB} .^{25}$ Likewise, a study conducted in Botswana reported that HIV patients whose BMI was less than 18.5 were four times more likely to develop TB compared to those with a higher BMI. ${ }^{26}$ In addition, a study conducted among patients on ART, indicated that individuals whose BMI is less than 18.5 were at risk of developing TB. ${ }^{27}$

The other important finding identified in this study was the association of the patient's baseline WHO clinical stage with TB/HIV co-infection. In this study, those HIV clients in the WHO clinical stages IV, III and II were about 23.02, 14.36 and 4.17 times more likely to develop TB compared with those in the WHO clinical stages I, respectively. It is comparable with previous study findings. ${ }^{11,28,29}$ This could be explained as once the patients get into late stages, the immunity protective capacity will be minimal which would make them prone to TB infection. Besides, TB is one of the AIDS-defining criteria to categorize the patients into the late WHO clinical staging which is also used as a criteria in HIV/AIDS clinics in Ethiopia. In the current study, ambulatory patients were 5 times more likely to develop TB than those working patients $(\mathrm{AOR}=5.30)$. This is consistent with the retrospective cohort studies conducted in Ethiopia. ${ }^{20,30}$

\section{Limitations of the Study}

The present study was a hospital-based study so that the findings might not be generalizable. During this study, sputum smear microscopy which has a low sensitivity 
among people living with HIV was used and thus could under-estimate the prevalence. Additionally, the effect of the use of TB preventive therapies on TB incidence was not evaluated.

\section{Conclusion and Recommendation}

The prevalence of TB/HIV co-infection among HIV infected individuals is high. Determinant factors, including drinking alcohol, a BMI less than 19, stage II, III and IV WHO clinical stages and ambulatory and bedridden HIV cases are significantly associated with TB/HIV co-infection. Therefore, diagnosis of TB among HIV sero-positive clients should be strengthened in HIV clinics. In addition, determinant factors of TB/HIV co-infections should be critically evaluated by the health staffs working in the HIV clinic.

\section{Abbreviations}

ART, Anti-Retroviral therapy; TB, Tuberculosis; HIV, Human Immunodeficiency Virus; WHO, World Health Organization.

\section{Data Sharing Statement}

The data could be accessed upon request.

\section{Ethics Approval and Consent to Participate}

Ethical clearance and permission letter were obtained from Motta district hospital administrative bodies. The study participants were informed about the purpose of the study and that it was conducted in accordance with the Declaration of Helsinki. Then, each study participant was included in the study after they gave their consent and their result was kept confidential. Those TB positive HIV sero-positive individuals were communicated to doctors in a TB clinic for treatment.

\section{Acknowledgments}

We kindly acknowledged Shegaw Motta district Hospital ethical review board for providing us the ethical clearance letter. Finally, we would like to thank the study participants who cooperated with us and Shegaw Motta district Hospital TB and ART clinic workers for giving us the necessary data.

\section{Funding}

There is no funding to report.

\section{Disclosure}

The authors report no conflicts of interest for this work.

\section{References}

1. Organization WH. Conveniomarco de la OMS para el control del tabaco: Directrices para la aplicación: Artículo 5.3, Artículo 8, Artículo 11, Artículo 13. World Health Organization; 2010.

2. Iliyasu Z, Babashani M. Prevalence and predictors of tuberculosis coinfection among HIV-seropositive patients attending the Aminu Kano Teaching Hospital, northern Nigeria. J Epidemiol. 2009;09 03030070 .

3. Walker NF, Meintjes G, Wilkinson RJ. HIV-1 and the immune response to TB. Future Virol. 2013;8(1):57-80.4 doi:10.2217/fvl.12. 123

4. AIDS Control and Prevention (AIDSCAP) project of family health internal tF-XBCfPHaHRotHSoPH, UNAIDS the status and trends of the global HIV/AIDS pandemic. Final Report July 5-6, 1996.

5. Raviglione MC, Narain JP, Kochi A. HIV-associated tuberculosis in developing countries: clinical features, diagnosis, and treatment. Bull World Health Organ. 1992;70(4):515.

6. Organization WH. Global Tuberculosis Report 2013. World Health Organization; 2013.

7. Organization WH. WHO Country Cooperation Strategy 2012-2015, Ethiopia. Republic of Congo: WHO Regional Office for Africa; 2013. Available from: http://www.afro.who.int/. Accessed November 25, 2020

8. (MOH) MoHoE. Tuberculosis, Leprosy and TB/HIV Prevention and Control Programme Manual. Addis Ababa: MOH; 2008:4.

9. Organization WH, Initiative ST. Treatment of Tuberculosis: Guidelines. World Health Organization; 2010.

10. Taha M, Deribew A, Tessema F, Assegid S, Duchateau L, Colebunders R. Risk factors of active tuberculosis in people living with HIV/AIDS in southwest Ethiopia: a case control study. Ethiop $J$ Health Sci. 2011;21(2):131-140.

11. Akanbi MO, Achenbach CJ, Feinglass J, et al. Tuberculosis after one year of combination antiretroviral therapy in Nigeria: a retrospective cohort study. AIDS Res Hum Retroviruses. 2013;29(6):931-937. doi:10.1089/aid.2012.0231

12. Molaeipoor L, Poorolajal J, Mohraz M, Esmailnasab N. Predictors of tuberculosis and human immunodeficiency virus co-infection: a casecontrol study. Epidemiol Health. 2014;36.

13. Administration MW. Annual Statistical Jornal. Motta, Ethiopia: Motta Wereda Administration; 2018.

14. Wondimeneh Y, Muluye D, Belyhun Y. Prevalence of pulmonary tuberculosis and immunological profile of HIV co-infected patients in Northwest Ethiopia. BMC Res Notes. 2012;5(1):331. doi:10.1186/ 1756-0500-5-331

15. Riello FN, Brígido RT, Araújo S, Moreira TA, Goulart LR, Goulart IM. Diagnosis of mycobacterial infections based on acid-fast bacilli test and bacterial growth time and implications on treatment and disease outcome. BMC Infect Dis. 2016;16(1):142. doi:10.1186/ s12879-016-1474-6

16. Kamath RSV, Pattanshetty S, Hegde M, Chandrasekaran V. HIV-TB coinfection: clinico-epidemiological determinants at an antiretroviral therapy center in southern India. Lung India. 2013;30(4):302-306. doi:10.4103/0970-2113.120605

17. Prado DMA, Souza F, Dias E, et al. Factors associated with tuberculosis by HIV status in the Brazilian national surveillance system: a cross sectional study. BMC Infect Dis. 2014;14:415. doi:10.1186/ 1471-2334-14-415

18. Rajasekaran S, Mahilmaran A, Annadurai S, Kumar S, Raja K. Manifestation of tuberculosis in patients with human immunodeficiency virus: a large Indian study. Ann Thorac Med. 2007;2(2):58. doi:10.4103/1817-1737.32231 
19. Awoyemi O, Ige O, Onadeko B. Prevalence of active pulmonary tuberculosis in human immunodeficiency virus seropositive adult patients in University College Hospital, Ibadan, Nigeria. Afr J Med Med Sci. 2002;31(4):329-332.

20. Kibret KT, Yalew AW, Belaineh BG, Asres MM. Determinant factors associated with occurrence of tuberculosis among adult people living with HIV after antiretroviral treatment initiation in Addis Ababa, Ethiopia: a case control study. PLoS One. 2013;8(5):e64488. doi:10.1371/journal.pone.0064488

21. Tesfaye B, Alebel A, Gebrie A, Zegeye A, Tesema C, Kassie B. The twin epidemics: prevalence of TB/HIV co-infection and its associated factors in Ethiopia; a systematic review and meta-analysis. PLoS One. 2018;13(10):e0203986. doi:10.1371/journal.pone.0203986

22. Ngowi BJ, Mfinanga SG, Bruun JN, Morkve O. Pulmonary tuberculosis among people living with HIV/AIDS attending care and treatment in rural northern Tanzania. BMC Public Health. 2008;8(1):341. doi:10.1186/1471-2458-8-341

23. Lienhardt C, Fielding K, Sillah J, et al. Investigation of the risk factors for tuberculosis: a case-control study in three countries in West Africa. Int J Epidemiol. 2005;34(4):914-923. doi:10.1093/ije/ dyi100

24. Teck R, Ascurra O, Gomani P, et al. WHO clinical staging of HIV infection and disease, tuberculosis and eligibility for antiretroviral treatment: relationship to CD4 lymphocyte counts. Int J Tuberc Lung Dis. 2005;9(3):258-262.
25. Nakanjako D, Mayanja-Kizza H, Ouma J, et al. Tuberculosis and human immunodeficiency virus co-infections and their predictors at a hospital-based HIV/AIDS clinic inUganda. Int J Tuberc Lung Dis. 2010;14(12):1621-1628.

26. The 20th conference on retrovirus and opportunistic infection. Georgia world congress center Atlanta. March 3-6, 2013.

27. Worodria W, Massinga-Loembe M, Mayanja-Kizza H, et al. Antiretroviral treatment-associated tuberculosis in a prospective cohort of HIV-infected patients starting ART. Clin Dev Immunol. 2011;2011.

28. Lawn SD, Badri M, Wood R. Tuberculosis among HIV-infected patients receiving HAART: long term incidence and risk factors in a South African cohort. AIDS. 2005;19(18):2109-2116. doi:10.1097/ 01.aids.0000194808.20035.c1

29. Hill PC, Jackson-Sillah D, Donkor SA, Otu J, Adegbola RA, Lienhardt C. Risk factors for pulmonary tuberculosis: a clinic-based case control study in The Gambia. BMC Public Health. 2006;6 (1):156. doi:10.1186/1471-2458-6-156

30. Fekadu S, Teshome W, Alemu G. Prevalence and determinants of tuberculosis among HIV infected patients in south Ethiopia. J Infect Dev Ctries. 2015;9(08):898-904. doi:10.3855/jidc.5667
International Journal of General Medicine

\section{Publish your work in this journal}

The International Journal of General Medicine is an international, peer-reviewed open-access journal that focuses on general and internal medicine, pathogenesis, epidemiology, diagnosis, monitoring and treatment protocols. The journal is characterized by the rapid reporting of reviews, original research and clinical studies

\section{Dovepress}

across all disease areas. The manuscript management system is completely online and includes a very quick and fair peer-review system, which is all easy to use. Visit http://www.dovepress.com/ testimonials.php to read real quotes from published authors. 